\title{
Dear old friend darkness
}

\author{
Tam-Tri Le \\ Centre for Interdisciplinary Social Research \\ Phenikaa University, Hanoi, Vietnam \\ Written in Ho Chi Minh city, on July $13^{\text {th }}, 2021$ \\ OSF Preprints, DOI: 10.31219/osf.io/3fdka
}

In July 2021, Ho Chi Minh city - where I am currently staying - entered a state of stricter lockdown due to a big wave of COVID-19 infection. I have heard stories about lockdowns from all over the world since early 2020, but now I am the one personally experiencing it. For an introvert who can work from home on the computer, my daily activities are not affected too much, but I can feel that the atmosphere of my neighborhood surely did change.

All my family members stay inside the house, only mom going to the local store every couple of days to buy food. She is the only one who can now and then observe the town with her own eyes. The typically chaotic streets became deserted, vendors and markets are closed, and people are simply afraid to meet each other. While essential items and food are still accessible, the normal variety, abundance, and the familiar urban scenery are now gone. Fresh vegetables and fruits have become the rare and hot commodities (in a tropical country!). They can be sold out in minutes after supply arriving at the store as people swiftly trade then hide like shadowy ninjas.

These days, while mom shared some comical stories about her ventures outside (short shopping trips), dad often talked about his memories of the $20^{\text {th }}$ century's late decades. The overall atmosphere of isolation, hardship, and the fear of the unknown reminded him of those young days when he had to fight against hunger, soldiers, the jungle, diseases, and the confusion about the future. Those were his haunting memories.

Talking about a visit from the past, our current Prime Minister - Mr. Pham Minh Chinh - is putting a lot of effort into combating the infection wave, especially in Ho Chi Minh city [1]. Interestingly, he is the one who wrote (co-authored with Dr. Vuong Quan Hoang) a major book about Vietnam's economic challenges and transformations throughout the late $20^{\text {th }}$ century [2]. Now big problems have again visited our country, but in a different context. Challenges coming in new forms requires solutions with innovation. And this time, not only we have precious insights from our own history, the global battle against COVID-19 also holds a lot of valuable lessons that Vietnam can use to effectively formulate the answers for our case [3].

Eastern wisdom often mentions about "returning to the old place and seeing through the new eye". In a sense, with the current situation I can contemplate on various levels of this concept in Vietnam's socio-economic state, the people of my parents' generation, and personally myself. 
Under the hand of fate, here I am staying in this small room alone day by day just like what happened last year, and just like what happened 10 years ago. History does not repeat, it recreates. And life is here not for the soul to relive the pain, but to find ways to relieve it. Dark times come also as chances to realize what is now able to be realized.

And in this sound of silence, I again borrow the famous lines from Simon and Garfunkel, for it means differently and more each time I recall.

"Hello darkness, my old friend; I've come to talk with you again."

\section{References}

1. Hà Văn. (2021). Cả nước sát cánh cùng TP. HCM, quyết tâm đẩy lùi đợt dịch cam go nhất. Tạp chí Kinh tế và Dự báo. https://kinhtevadubao.vn/ca-nuoc-sat-canh-cung-tphcm-quyet-tam-day-lui-dot-dich-cam-go-nhat-18278.html

2. Phạm Minh Chính, \& Vương Quân Hoàng (2009). Kinh tế Việt Nam: Thăng trầm và đột phá. Nxb Chính trị Quốc gia, Hà Nội.

3. Vuong, Q.-H., et al. (2021). Covid-19 vaccines production and societal immunization under the serendipity-mindsponge-3D knowledge management theory and conceptual framework [Preprint]. SocArXiv. https://doi.org/10.31235/osf.io/4mchu 